DOI: $10.14451 / 1.178 .82$

\title{
СПЕЦИАЛЬНЫЙ ИНВЕСТИЦИОННЫЙ КОНТРАКТ В УПРАВЛЕНИИ ПРИВЛЕЧЕНИЕМ ЧАСТНЫХ ИНВЕСТИЦИЙ В МОДЕРНИЗАЦИЮ ПРОМЫШЛЕННОСТИ
}

\author{
(c) 2019 Зельднер Алексей Григорьевич \\ доктор экономических наук, профессор, главный научный сотрудник \\ Институт экономики Российской академии наук, Россия, Москва \\ Email: tzeldner@gmail.com
}

Развитие современных отраслей промышленности на инновационно-технологической основе в условиях ограниченных бюджетных средств требует эффективных механизмов привлечения инвесторов в создание промышленных производств на новой технологической базе. Этому в значительной мере будут способствовать и специальные инвестиционные контракты. В статье рассматривается системный подход к функционированию специнвестконтрактов и проблемы повышения эффективности их реализации.

Ключевые слова: специальный инвестиционный контракт, промышленность, стимулирование, налоги, технологии.

Специальный инвестиционный контракт, как форма соглашения государства и инвестора перспективный инструмент промышленной политики, механизм стимулирования привлечения частных инвестиций в создание и модернизацию современных инновационно-технологических промышленных предприятий, обеспечивающих локализацию производства на территории страны и импортозамещение. Специнвестконтракт, по сущности, форма государственно-частного партнерства, по содержанию,- в широком смысле, модифицированная форма концессионных соглашений.

К различным формам ГЧП, связанным с совместным участием государства и бизнеса в реализации крупных инвестиционных проектов с использованием льгот по налогам и таможенных преференций, добавилась еще одна разновидность модифицированной формы ГЧП специальный инвестиционный контракт.

Правовая основа специальных инвестиционных контрактов (СПИК) первоначально была изложена в Федеральном законе от 31.12.2014. № 488-Ф3 «О промышленной политике в РФ» (ст. 16)*. В Законе речь шла, как о специнвестконтрактах с участием федеральных, региональных и муниципальных властей, так и о стимулировании привлечения частных инвестиций. Постановлением Правительства РФ от 16.07.2015 г. № 708 «О специальных инвестиционных кон- трактах для отдельных отраслей промышленности» утверждены правила и порядок заключения СПИК, которые по мере накопления опыта совершенствуются. Так, Постановлением Правительства РФ № 1564 (декабрь 2017 г.) внесено изменение, позволяющее учитывать денежные средства, вложенные в СПИК до его подписания, при этом для нового этапа дополнительно вносится не менее 750 млн. рублей, а общий объем инвестиций составляет не менее $50 \%$ общего объема инвестиций, необходимых в целом по СПИК. Одновременно разрешено участие в проекте «привлеченных лиц».

Специальный инвестиционный контракт заключается между государством и инвестором, позволяет объединять возможности и делить риски. Это, по сути, контракт партнерских отношений. В соответствии с Федеральным законом № 380 «О хозяйственном партнерстве» (от 03.12.2013 г.) партнерство может быть оформлено как юридическое лицо. Если партнерство оформляется в виде контракта, то формальная сторона контракта регулируется Гражданским кодексом и нормативными гражданско-правовыми документами, имеющими отношения к контрактам. Участие государства в специальном инвестиционном контракте определяется Бюджетным кодексом (ст. 78), в соответствии с которой все стимулы, предоставляемые физическим и юридическим лицам,

\footnotetext{
"Первый СПИК был подписан с немецкой компанией «Клаас» по проекту модернизации завода сельскохозяйственных машин в Краснодаре.
} 
(включая индивидуальных предпринимателей), предоставляются в указанных в Законе целях на безвозмездной основе.

В пункте 3а Постановления Правительства № 708 отмечается, что под инвестиционным проектом по модернизации производства промпродукции понимается проект по внедрению наилучших доступных технологий на промпредприятиях РФ. А в пункте $3 б$ этого же Постановления дается определение спецконтракта по освоению промпродукции: «Под инвестиционным проектом по освоению производства промышленной продукции понимается проект, отнесенный к промышленной продукции, не имеющей произведенных в РФ аналогов» [1].

Наиболее существенные улучшения в совершенствовании специнвестконтрактов внесены в соответствии с Федеральным законом № 290Ф3, подписанным Президентом 2 августа 2019 г. Речь в нем идет о внесении изменений в Федеральный закон «О промышленной политике в РФ» в части регулирования специнвестконтрактов [2]. Со дня вступления в силу Закона 290-ФЗ статья 16 Федерального закона от 31 декабря 2014 г. № 488-Ф3 «О промышленной политике в Российской Федерации» применяется только к отношениям, возникающим при заключении, изменении, расторжении специальных инвестиционных контрактов.

В соответствии со ст. 18.2 ФЗ-290 (пункт 3) СПИК заключается на срок не более 15 лет для реализации проекта, объем инвестиций по которым не превышает 50 млрд. руб. (без НДС), или на срок более 20 лет, объем инвестиций по которым превышает 50 млрд. руб. СПИК заключается в порядке, установленном Правительством, по результатам проведенного открытого или закрытого конкурсного отбора. Введены исключения: открытый конкурсный отбор на право заключения СПИК проводится по инициативе Российской Федерации и совместно РФ, субъект РФ и муниципальное образование, а также инвесторы. Закрытый конкурсный отбор на право заключения СПИК проводится при реализации проектов технологий военного, специального или двойного назначения... (статья 18 пункт 4 часть 5). «Специальный инвестиционный контракт заключается без проведения конкурсного отбора в следующих случаях: 1) при наличии решения Президента Российской Федерации о заключении специального инвестиционного контракта в целях реализации проекта, имеющего стратегическое значение для развития экономики Российской Федерации или обеспечения национальной безопасности, на условиях, предложенных инвестором и соответствующих настоящему Федеральному закону; 2) если при проведении конкурсного отбора была подана только одна заявка, соответствующая требованиям, установленным настоящим Федеральным законом, актом Правительства Российской Федерации и документацией о проведении конкурсного отбора».

В 290-ФЗ установлена паритетная ответственность за невыполнение обязательств по СПИК - предусмотрено возмещение реального ущерба и уплата штрафов в соответствии с положением контракта. Упущенная выгода возмещению не подлежит.

Механизм реализации СПИК, как формы ГЧП, достаточно понятен: инвестор за счет своих сил и средств в предусмотренный срок обязуется создать (модернизировать) и освоить производство промышленной продукции на территориях России, а РФ или ее субъект обязуются обеспечить финансовую поддержку в виде льгот по налогам и сборам в рамках законодательства. Оператором по заключению СПИК выступает Фонд развития промышленности.

Помимо налоговых льгот и субсидий на инфраструктуру для СПИК вводятся и спецусловия. Спецусловия на федеральном уровне также включают компенсацию затрат на уплату процента по кредитам; право на ускоренную амортизацию (на основные средства, используемые в процессе реализации СПИК); компенсацию импортных затрат; получение статуса «единственного поставщика товаров для госзакупок»". Спецусловия регионального и муниципального плана в основном касаются соответствующих налогов. При этом региональный СПИК возможен только при принятии субъектами своего законодательства. Государство гарантирует неизменность условий СПИК и сохранение стабильности налоговых ставок на весь контракт. Каждый инвесторов на стадии заключения контракта, исходя из специфики проекта, согласовывает систему налоговых льгот и своих обязательств,

\footnotetext{
" Правительство вправе определить участника СПИКА единственным поставщиком товаров для закупок в целях обеспечения государственных и муниципальных нужд. Но для этого объем инвестиций должен превысить 3 млрд. руб. [8], а страной происхождения товара должна быть Россия.
} 
что в итоге определяет дифференциацию проектов по стимулам. В соответствии с Федеральным законом № 269-ФЗ от 2 августа 2019 г. «О внесении изменений в части первую и вторую Налогового Кодекса РФ» отмечается, что «для налогоплательщиков СПИК налоговая ставка, подлежащая зачислению в федеральный бюджет, устанавливается в размере 0 процентов». Аналогичные возможности имеют и субъекты РФ. При использовании пониженной до 0\% ставки налога на прибыль (федеральный и региональный аспект) имеется ряд обременений, включающий следующие условия: ведение раздельного учета доходов и расходов, полученных от СПИК и иной деятельности; доходы от реализации товаров от деятельности специнвестпроекта должны составлять не менее 90\% всех доходов.

Вопрос о том, выступает ли специальный инвестиционный контракт формой государственно-частного партнерства в промышленности и других отраслях, вызвал определенную дискуссию. Проблемными вопросами дискуссии выступают: финансовая поддержка государства, связанная с промышленной инфраструктурой в виде субсидий. По мнению ряда авторов, исходя из того, что в Правилах заключения СПИК меры стимулирования не конкретизируются, «частный партнер принимает на себя обязательства финансового характера, публичный же партнер предоставляет частному партнеру преимущественно преференции и изъятия. Таким образом, в данном инвестиционном проекте не предусматривается софинансирование расходов. У специального инвестиционного контракта и соглашения о ГЧП (или любой другой контрактной формы ГЧП) разные цели: у первого - создание для субъекта производственной деятельности благоприятных условий для инвестиционной деятельности, у второго - создание, реконструкция объектов инфраструктуры или осуществление деятельности в сфере ответственности государства. Таким образом, специальный инвестиционный контракт только в широком понимании может считаться формой государственно-частного партнерства» [3]. Судя по заключению, авторы понимают уязвимость своего теоретического осмысления ГЧП, но опираются на формальную трактовку федеральных законов.

Специальный инвестиционный контракт одна из форм ГЧП, в которой предусмотрено соучастие в проекте за счет софинансирования государством создание промышленной инфраструктуры. Вообще сложно представить себе развитие промышленности как самоцель без взаимосвязанного решения ее инфраструктурных проблем. И поэтому государством в ФЗ № 488 от 31.12.2014. «О промышленной политике в РФ» предусмотрена финансовая поддержка в форме субсидий на финансирование, создание или модернизацию промышленной инфраструктуры (ст. 9 ФЗ № 488 и п. 2 ст. 10 ФЗ № 488). Более того, в Типовой форме СПИК, утвержденной Постановлением Правительства РФ от 16 июля 2018 г. № 708 (в редакции от 16.12.2017 г. № 1546) допускается возможность (в обязательствах РФ) предоставление субсидий инвестору или промпредприятию в пределах бюджетных ассигнований, предусмотренных законом о федеральном бюджете (ст. 6 п. 3)*.

В обеспечении инвесторов СПИК субсидиями активное место занимает Фонд развития промышленности, который выступает оператором механизма СПИК, субсидируя процентные ставки по кредитам на реализацию новых инвестпроектов. Субсидии также устанавливаются из федерального бюджета на компенсацию части затрат на уплату процентов по кредитам и части купонного дохода по облигациям (20172019 гг.). Для целей реализации специнвестпроектов ФРП предоставляет также займы на запуск оборудования, запуск производств, опытно-конструкторских работ.

Промышленная инфраструктура, согласно Ф3 № 488 включает: транспортную и коммунальную инфраструктуру, а также объекты недвижимого имущества, необходимые для функционирования промышленности. По сути, это базовая основа функционирования промышленного предприятия и выступает органичной

\footnotetext{
" В последних Законах рассматривается и порядок возврата субсидий. В ФЗ № 290 от 2.09.2019 (статья 18.5 часть 3) отмечается, что в случае расторжения контракта уплата в бюджет суммы налога или возврата суммы «предоставленной субсидии в соответствии с бюджетным законодательством Российской Федерации, суммы указанных налога и (или) субсидии уплачиваются либо возвращаются в соответствии с законодательством о налогах и сборах или бюджетным законодательством Российской Федерации и исключаются из суммы реального ущерба возмещаемого инвестором за невыполнение или ненадлежащее выполнение обязательств по специальному инвестиционному контракту»
} 
составляющей СПИК, позволяющей достигать целей государственных программ. В правилах заключения СПИК (постановление Правительства РФ от 16 декабря 2017 г. № 1546) в п. 5 подчеркивается «Специальный инвестиционный контракт заключается в целях решения задач и достижения целевых показателей и индикаторов государственных программ РФ в отраслях промышленности, в рамках которых реализуются инвестиционные проекты» [4].

Постепенно расширяется сфера деятельности СПИК. Если на конец 2018 г. было заключено 17 специнвестпроектов, то по данным Фонда развития промышленности, на 31.07.2019 г. было подписано уже 45 контрактов. Помимо Минпромторга РФ правом на заключение контрактов наделены почти все сырьевые министерства, Минэнерго и даже Минсельхоз РФ. И в то же время наблюдается дифференциация в подходах к заключению СПИК в зависимости от уровня возможных льгот, предоставляемых на федеральном, региональном и муниципальном уровнях. Так, из общего количества специнвестконтрактов, подписанных на начало 2019 г., «одной из сторон выступает РФ, в 29 из них субъекты РФ, на территории которых размещены производственные мощности, также выступают стороной соглашения, и только в два специнвестконтракта вошли органы местного самоуправления» [5]. Общий объем инвестиций на 31.08.19-807,8 млрд. руб., количество созданных рабочих мест 23,9 тыс., отраслевое распределение: в приоритете автомобильная промышленность - 14 контрактов, химический комплекс - 8 контрактов, фармацевтика -7 , машиностроение 4 , станкостроение -3 контракта, три специнвестконтракта - по другим отраслям [6].

Положительный опыт по привлечению за счет СПИК иностранных инвестиций накоплен в Китае. Опыт Китая в стимулировании привлечения иностранных инвестиций и технологий, отработанный при создании особых экономических зон, позволил эффективно использовать и СПИК. За относительно короткий срок с 1991 по 1998 гг. объем прямых инвестиций в Китай вырос с 4,4 млрд. долл. до 45,5 млрд. долл. (Российская газета 10 июля 2016 г.). Этому способствовали система налоговых льгот и таможенных преференций, предоставляемых инвесторам, две трети продукции которых идет на экспорт. В России Китай получил одобрение Минпомторга на льготы при заключении СПИК. Предприятие «Хавейл» инвестирует свыше 42 млрд. руб. в «глубокую локализацию ключевых компонентов», которые будут ставить на выпускаемые ими же в России автомобили. Планируется создать дополнительно около 900 рабочих мест.

В заключение отметим, что несмотря на небольшой срок функционирования СПИК, он дает основание для предложений по дальнейшему совершенствованию этого важнейшего механизма модернизации промышленной политики и импортозамещения.

1. В Правилах заключения специнвестконтрактов (Постановление Правительства РФ от 16.12.2017 № 1546 в разделе 13) инвестор предоставляет в уполномоченный орган заявление о заключении СПИК с приложениями. В пункте 13-м предоставляется «справка с указанием структуры (схемы) участников инвестиционного проекта, в том числе лиц, заинтересованных в реализации инвестиционного проекта, не являющихся инвестором или привлеченными лицами (в состав участников инвестиционного проекта могут включаться в том числе заинтересованные лица, то есть лица, которые имеют право на получение более 20 процентов чистой прибыли инвестора (привлеченных лиц) и (или) которые предоставляют более 20 процентов общего объема средств для финансирования инвестиционного проекта (кроме финансовых организаций, институтов развития), а также основные поставщики материалов и комплектующих, необходимых для производства промышленной продукции, или покупатели промышленной продукции, планируемой к выпуску в результате реализации инвестиционного проекта (в случае если соответствующие поставщики и (или) покупатели известны на дату подачи заявления о заключении специального инвестиционного контракта)».

По нашему оценочному мнению, привлечение в участники инвестпроекта лиц, заинтересованных в реализации проекта, но не выступающих инвесторами, по сути, означает официальное включение лоббистов. А в условиях отсутствия закона о лоббизме и конкуренции, это открытая дорога к дифференциации условий функционирования предприятий.

2. Усложнена иерархическая лестница прохождения процесса заключения специнвестконтрактов. Согласование проекта проходит следующие этапы: Минпромторг, региональные 
власти, Фонд развития промышленности и, наконец, Межведомственная комиссия по оценке возможности заключения СПИК, и все это сопровождается большим количеством справок и материалов, существенно затягивающих заключение проекта, практически до одного года. Необходимо упростить схему подготовки и заключения СПИК, сократить срок оформления контрактов и объем требуемой документации и отчетности. Опрос, проведенный среди членов РСПП, показал необходимость совершенствования механизма СПИК в направлении снятия «ограничения на период применения льготной ставки по налогу на прибыль до 2025 г., штрафных санкций за отклонение ключевых показателей реализации проекта от плановых» и другие [7].
3. При заключении специальных инвестиционных контрактов на федеральном, региональном и, возможно, на муниципальном уровне возникает проблема недостаточной открытости условий заключения контрактов. Связано это с тем, что для СПИК могут устанавливаться спецусловия на всех уровнях (федеральном, региональном, муниципальном), исходя из специфики и важности контракта, что в итоге может приводить к дифференциации предприятий по стимулам и субсидиям. На дифференциацию по стимулам может оказывать влияние и имеющиеся по каждому налогу обременения. Необходимо создать единое открытое правовое поле, отражающее неизменность налоговых, тарифных и таможенных условий, получение субсидий и других мер государственной поддержки.

\section{Библиографический список}

1. Постановление Правительства РФ от 16 июля 2015 г. № 708 «О специальных инвестиционных контрактах для отдельных отраслей промышленности (в ред. от 18.06.2018) https://meganorm.ru/ Data2/1/4293762/4293762385.htm

2. Федеральный закон РФ от 2 августа 2019 г. № 290-ФЗ «О внесении изменений в Федеральный закон «О промышленной политике в Российской Федерации» в части регулирования специальных инвестиционных контрактов» http://www.consultant.ru/document/cons_doc_LAW_330685/

3. Ткаченко И.Н., Евсеева М.В. Возможность применения контрактных форм государственно-частного партнерства и специального инвестиционного контракта при реализации комплексных инвестиционных проектов развития территорий // Государственно-частное партнерство. Т. 3. № 4. М. 2016. С. 276-277

4. https://meganorm.ru/Data2/1/4293762/4293762385.htm

5. Евстафьева Ю.В. Опыт применения и совершенствование специального инвестиционного контракта. Вестник ИЭ РАН. № 3. 2019. С. 158, 160.

6. https://frprf.ru/download/prezentatsiya-mekhanizma-spetsialnykh-investitsionnykh-kontraktov-popostanovleniyu-pravitelstva-708-ot-16-07-2015.pdf

7. Глухова М., Шохин А. Специальный инвестиционный контракт: взгляд бизнеса. Власть. 2017. № 7. С. 11-12.

8. Лоссан А. Очередь за инвестициями. Ж. ВВП № 37 2016. С. 129

9. Федеральный закон РФ от 31.12.2014. № 488-ФЗ «О промышленной политике в Российской Федерации». 